\title{
Author Correction: Streptomyces monashensis sp. nov., a novel mangrove soil actinobacterium from East Malaysia with antioxidative potential
}

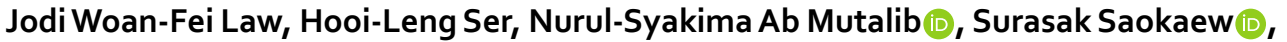 \\ Acharaporn Duangjai, Tahir Mehmood Khan, Kok-Gan Chan $\mathbb{D}$, Bey-Hing Goh \& \\ Learn-Han Lee
}

Correction to: Scientific Reports https://doi.org/10.1038/s41598-019-39592-6, published online 28 February2019

The original version of this Article contained typographical errors in the Abstract and the Main Body of the text.

In the Abstract

"Streptomyces monashensis MUSC $1 \mathrm{~J}^{\mathrm{T}}\left(=\mathrm{DSM} 103626^{\mathrm{T}}=\mathrm{MCCC} 1 \mathrm{~K} 03221^{\mathrm{T}}\right)$ could potentially be a producer of novel bioactive metabolites; hence discovery of this new species may be highly significant to the biopharmaceutical industry as it could lead to development of new and useful chemo-preventive drugs."

now reads:

"Streptomyces monashensis MUSC $1 \mathrm{~J}^{\mathrm{T}}\left(=\mathrm{DSM} 103626^{\mathrm{T}}=\mathrm{MCCC} 1 \mathrm{~K} 03219^{\mathrm{T}}\right)$ could potentially be a producer of novel bioactive metabolites; hence discovery of this new species may be highly significant to the biopharmaceutical industry as it could lead to development of new and useful chemo-preventive drugs."

Under the sub-heading Description of Streptomyces monashensis sp. nov

“The type strain is MUSC $1 \mathrm{~J}^{\mathrm{T}}\left(=\mathrm{DSM} 103626^{\mathrm{T}}=\right.$ MCCC $\left.1 \mathrm{~K} 03221^{\mathrm{T}}\right)$ isolated from mangrove sediments collected from the Sarawak mangrove forest located in East Malaysia. The 16S rRNA gene sequence of strain MUSC $1{ }^{\mathrm{T}}$ has been deposited in GenBank/EMBL/DDBJ under the accession number KP998432."

now reads:

“The type strain is MUSC $1 \mathrm{~J}^{\mathrm{T}}\left(=\mathrm{DSM} 103626^{\mathrm{T}}=\right.$ MCCC $\left.1 \mathrm{~K} 03219^{\mathrm{T}}\right)$ isolated from mangrove sediments collected from the Sarawak mangrove forest located in East Malaysia. The 16S rRNA gene sequence of strain MUSC $1 \mathrm{~J}^{\mathrm{T}}$ has been deposited in GenBank/EMBL/DDBJ under the accession number KP998432."

In the Conclusion section

"The name Streptomyces monashensis sp. nov. is proposed and the type strain is MUSC $1 \mathrm{~J}^{\mathrm{T}}(=\mathrm{DSM}$ $103626^{\mathrm{T}}=$ MCCC 1 K03221 $1^{\mathrm{T}}$.”

now reads:

"The name Streptomyces monashensis sp. nov. is proposed and the type strain is MUSC $1 \mathrm{~J}^{\mathrm{T}}(=\mathrm{DSM}$ $103626^{\mathrm{T}}=$ MCCC $\left.1 \mathrm{~K} 03219^{\mathrm{T}}\right)$."

This has now been corrected in the PDF and HTML versions of the Article. 
(c) (i) Open Access This article is licensed under a Creative Commons Attribution 4.0 International License, which permits use, sharing, adaptation, distribution and reproduction in any medium or format, as long as you give appropriate credit to the original author(s) and the source, provide a link to the Creative Commons license, and indicate if changes were made. The images or other third party material in this article are included in the article's Creative Commons license, unless indicated otherwise in a credit line to the material. If material is not included in the article's Creative Commons license and your intended use is not permitted by statutory regulation or exceeds the permitted use, you will need to obtain permission directly from the copyright holder. To view a copy of this license, visit http://creativecommons.org/licenses/by/4.0/.

(C) The Author(s) 2020 